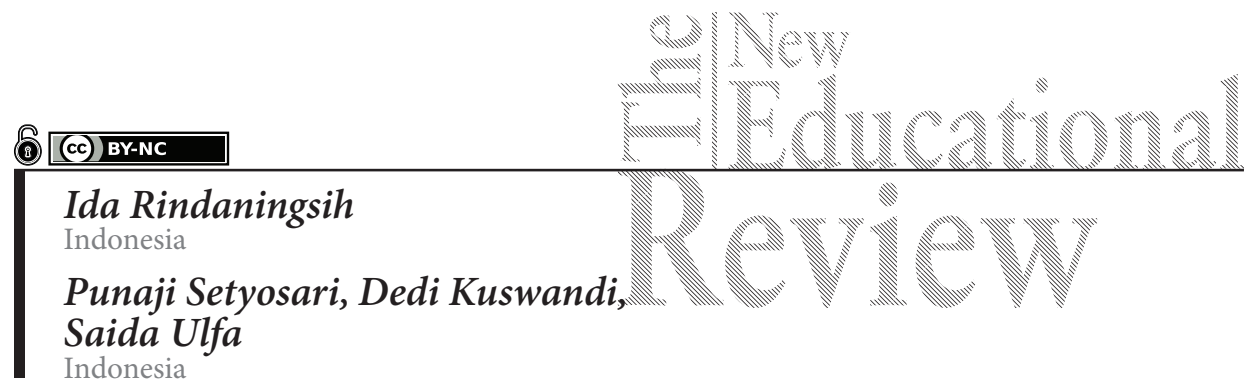

\title{
Development of Seamless Learning to Facilitate Formal and Informal Learning in Elementary Education
}

DOI: 10.15804/tner.2020.61.3.04

\begin{abstract}
Environmental education in primary schools has not built sufficient awareness in formal-informal learning experience. The development of seamless learning is an alternative innovation in building students' learning experiences. However, there is limited research on its implementation in the learning process in elementary schools with limited mobile technology. Therefore, the purpose of this research was to develop instructional design and learning planning matrices for seamless learning on teachers' and students' activities to facilitate formal and informal learning with limited use of mobile technology in elementary schools. Based on the instructional design and learning planning matrices developed, the context reconstruction in a seamless learning design was successfully used in guiding the teachers' and students' activities. The limitations of mobile technology in the schools could be replaced with the use of learning laboratories, as well as parents' support at home. Furthermore, the instructional design and learning matrix developed were feasible, valid, and practical in application in elementary schools. Therefore, the community has a vital role to play in improving students' learning experiences aside from schools.
\end{abstract}

Key words: instructional design, learning planning matrices, learning activity, mobile technology. 


\section{Introduction}

Environmental education could improve students' awareness and appropriate behaviour towards nature. Environmental education could be integrated into school curricula as an independent subject in the formal education system. This integrated approach has been used in some countries such as Uganda, China, Finland and New Zealand (Bian, 2004). The approaches used in integrating environmental education into school curricula vary widely, such as its integration into subject matter, parents' involvement, etc. (Sureda-Negre et al., 2014). Education system teaches students to live in a way which promotes sustainable ecological balance. Similarly, the Ministry of Environment and Forestry, together with the Ministry of Education in Indonesia, implemented the "Adiwiyata" school development programs to sustain this initiative. An Adiwiyata School means a school that cares for and loves the environment. Lack of love for the environment is due to low or non-existent awareness in schools and homes. Learning about caring for the environment at school could also be enhanced at home through the support of parents, families or the community at large.

Additionally, technological limitations are a major problem in environmental education. Most teachers are not skilled in utilizing the facilities available to support quality learning, while inadequate facilities are another major problem, hence the need to for links between learning activities inside and outside the classroom. This is supported by the seamless learning method developed by Sun \& Looi, 2019; Zhang \& Looi, 2011. This seamless method is an alternative in bridging between formal and informal learning. According to Wong \& Looi (2011), this method is developing rapidly with 10 layers of Mobile Seamless Learning. In addition, some developed countries have shown the importance of the seamless method as a multifaceted learning effort across several spaces at all education levels in general knowledge, language, science, and mathematics using advanced technological tools (Amhag, 2017; Song, 2018).

\section{Problem of Research}

Seamless learning has provided a platform for researchers to develop different concepts, yet it still leaves some problems, such as accumulation of experiences and the improvement of learning interventions inside and outside of school (Song \& Kong, 2014). Recent research has reported the lack of adequate explanation on each level of Mobile Seamless Learning (MSL) capable of improving learning experiences of students. Furthermore, there is a need to develop the theory foundation obtained as a concept in each layer of MSL. Wong (2013) stated the main 
characteristics of using mobile learning are as follows; (a) mobility, where learning is moving and not fixed in a physical location and (b) personalization, in which learning is more personal in a context which is being continuously reconstructed. According to Dilger et al. (2019), educational designers are needed in the learning process to create specific objectives in each layer of the MSL dimension.

\section{Research Focus}

Based on the explanations above, it can be concluded that research into the development of seamless learning focused on the instructional design, including learning planning matrices has not been done in the formal and informal dimensions. Also, educational design research in authentic contexts and learning evaluation is a vital part of teacher and student activities based on the curriculum. According to Auguste, Kihn, \& Miller (2010), it is important for teachers to have freedom in planning class trials in achieving earning goals in elementary education. The purpose of this research aims at developing instructional design and learning planning matrices for seamless learning in teachers' and students' activities to facilitate formal and informal learning with limited use of mobile technology in elementary schools.

\section{Methodology of Research}

\section{General Background of research}

This research is a type of developmental research. Seamless learning for elementary school students was developed on the material "Love the Environment" in the natural sciences. The development of seamless learning is conducted by constructing the instructional design, and then proceeded with constructing learning planning matrices. It is focused on the development of teacher and student activities, thereby enhancing learning in both formal and informal settings. The elementary school provided a representative learning environment and facilities such as laboratories, computer rooms, libraries, school health unit rooms, etc. In addition, students could make use of mobile or computer facilities with parents' assistance to browse, download, take pictures, make videos and upload assignments. Seamless learning was developed through several components such as space, time, context, community, cognitive tools and artifacts (Seow et al., 2008),. The researcher used these components to construct instructional design for the teachers' and students' activities, both in formal and informal contexts, thereby implementing it in elementary school learning. This formal and informal seamless 
learning instructional design was based on the basic pedagogical theory and took into consideration conditions in elementary school.

\section{Instrument and Procedures}

The instruments for testing instructional design development using the seamless learning component is listed in Table 1.

Table 1. Instruments for developing instructional design on seamless learning

\begin{tabular}{|c|c|c|}
\hline $\begin{array}{l}\text { Seamless } \\
\text { Component }\end{array}$ & Definition & $\begin{array}{c}\text { Development of instructional } \\
\text { design }\end{array}$ \\
\hline Space & $\begin{array}{l}\text { Students are capable of moving seam- } \\
\text { lessly between different spaces physically } \\
\text { and virtually. }\end{array}$ & $\begin{array}{l}\text { Displaying Student Activities in the } \\
\text { Classroom - in the Learning Labora- } \\
\text { tory - and at home with the support } \\
\text { of Mobile Technology. }\end{array}$ \\
\hline Time & $\begin{array}{l}\text { Extending the task completion time } \\
\text { helps to build understanding up to the } \\
\text { point of analyzing through communica- } \\
\text { tion and collaborative efforts }\end{array}$ & $\begin{array}{l}\text { The length of time needed in build- } \\
\text { ing knowledge could be spent in the } \\
\text { Classroom, in the Learning laborato- } \\
\text { ry, in the Home supported by Mobile } \\
\text { Technology based on each student's } \\
\text { respective abilities until evaluated by } \\
\text { the teacher }\end{array}$ \\
\hline Context & $\begin{array}{l}\text { The ability of students to complete tasks } \\
\text { both in class, in the laboratory and at } \\
\text { home using their respective strategies }\end{array}$ & $\begin{array}{l}\text { Independence and strategies to } \\
\text { complete tasks starting from the } \\
\text { Classroom - Learning Laborato- } \\
\text { ry - home and with the support of } \\
\text { mobile technology in accordance } \\
\text { with their respective abilities }\end{array}$ \\
\hline Community & $\begin{array}{l}\text { Communities in a seamless learning } \\
\text { environment consist of students, teach- } \\
\text { ers, and community-based knowledge } \\
\text { forum, showing how individuals } \\
\text { contribute to building knowledge in the } \\
\text { community. This basically involves the } \\
\text { parents and the whole community }\end{array}$ & $\begin{array}{l}\text { The community generally contrib- } \\
\text { utes to the learning process in the } \\
\text { laboratory and at home, both online } \\
\text { and offline utilizing all available } \\
\text { resources. }\end{array}$ \\
\hline Tools & $\begin{array}{l}\text { Smartphone as a tool to measure cogni- } \\
\text { tive knowledge }\end{array}$ & $\begin{array}{l}\text { Computers at the learning laborato- } \\
\text { ry in school and at home }\end{array}$ \\
\hline Artifacts & Suitability of student work & $\begin{array}{l}\text { Evaluation of learning outcomes or } \\
\text { artifacts with presentations }\end{array}$ \\
\hline $\begin{array}{l}\text { Overall } \\
\text { Design }\end{array}$ & $\begin{array}{l}\text { The processes involved during the learn- } \\
\text { ing in class, laboratory, and at home }\end{array}$ & $\begin{array}{l}\text { Overall formal and informal image } \\
\text { of the instructional design }\end{array}$ \\
\hline
\end{tabular}


In this research, the procedures of seamless learning instructional design were adapted from stages proposed by van den Akker (2013), that is, include preliminary investigation; theoretical embedding; empirical testing; documentation, analysis, and reflection on process and outcome (See Table 2).

Table 2. Stages of development research

\begin{tabular}{ll}
\hline \multicolumn{1}{c}{ Development Stage } & \multicolumn{1}{c}{ Research Activity } \\
\hline Preliminary investigation & $\begin{array}{l}\text { a. Reviewing the seamless learning literature } \\
\text { - Seamless learning component } \\
\text { - Seamless Learning and Mobile Seamless Learning Study } \\
\text { - Formal and informal learning activities } \\
\text { b. Analysis of needs and problems in elementary school } \\
\text { c. Analysis of gaps in formal and informal learning experiences }\end{array}$ \\
\hline Theoretical embedding & $\begin{array}{l}\text { A more systematic effort to apply the theoretical knowledge base in } \\
\text { the designs. Also, the instructional designs of teacher and student }\end{array}$ \\
& $\begin{array}{l}\text { activities on seamless learning (MSL) dimension 1 were developed } \\
\text { by the researchers. }\end{array}$ \\
\hline Empirical testing & $\begin{array}{l}\text { Empirical evidence to show practicality and effectiveness through } \\
\text { validation of instructional design of the teaching material „Love the } \\
\text { Environment" by experts and practitioners. }\end{array}$ \\
\hline $\begin{array}{l}\text { Documentation, analysis, } \\
\text { and reflection on process } \\
\text { and outcome }\end{array}$ & $\begin{array}{l}\text { Systematic documentation, analysis and reflection are carried out } \\
\text { on the overall design. The evaluation and implementation of the } \\
\text { results contribute to the expansion and specification of design and } \\
\text { methodologies. }\end{array}$ \\
\hline
\end{tabular}

\section{Data Analysis}

The qualitative and quantitative data obtained were subjected to analysis. Qualitative data analysis was performed on data in the form of criticism and suggestions from experts, while quantitative data analysis was carried out in the form of scores on each instrument item. Internal validity was tested through the expert review of five people with theoretical expertise and practical experience in instructional design. These were made up of three design experts from Electrical Engineering, Educational Technology, and Educational Science, while the remaining two were teachers with decades of teaching experience in grade 4 elementary schools. The experts evaluated the teachers' and students' activities based on seamless learning using a Likert scale: 5 (strongly agree); 4 (agree); 3 (neutral); 2 (disagree); 1 (strongly disagree). In this research, the feasibility of the design was determined by a minimum value of "good" from the experts and education practitioners. This was conducted, so that the instructional design developed could be considered feasible for applying in learning. 


\section{Results of Research}

\section{Preliminary investigation and theoretical embedding}

This instructional design was developed based on components of seamless learning, with formal and informal activities. The learning processes in these two stages are further divided into four sub-sections, which include; classroom, learning laboratories, outside the classroom (home), and evaluation. Each sub-section was assessed for its achievements using Bloom's taxonomy (Anderson et al., 2001). Additionally, the cognitive achievements of each student varied according to their abilities. Each section also shows the activities of teachers, students, parents as well as the role of technology (See Figure 1).

\section{Formal Learning Stage}

The classroom is the initial stage, which continues in the learning laboratory. The teacher acts as a facilitator and motivator, with the primary role of coordinating the learning process. The class time is 30 minutes in which students interact with the teacher using the material, group division and laboratory assignment. In addition, the teacher arranges the seamless learning plan and students are motivated to learn independently, by reading a series of materials, discussing within groups, sharing and completing assignments. In this classroom stage the aim is to build $\mathrm{C} 1$ and $\mathrm{C} 2$ cognitive abilities (see Table 4 below).

Learning laboratories support students in exploring and building their knowledge. The student activity in building C2 and C3 abilities (see Table 4 below) happen in this place, where students are directly connected with the learning resources and the environment. Learning laboratories could also be computer rooms, school environments, and include visits to learning resources such as museums, factories, etc. The teachers act as motivators and monitor student activities. Meanwhile, students work based on assignments, explore, search for information, discuss, and organize all the tasks. The teachers are also responsible for motivating and guiding students who have difficulty in organizing the given assignments. Students are obliged to sort out uncompleted tasks and complete them at home.

\section{Informal Learning Stage at Home}

This is the learning phase outside the classroom, where students continue with activities not yet completed while in the learning laboratory. These activities could be in the form of observations, experiments, analysis, discussion with friends online and offline, documentation of activities, and uploading of assignments based on the achievements of C3, C4, and C5 (see Table 4 below). During this 


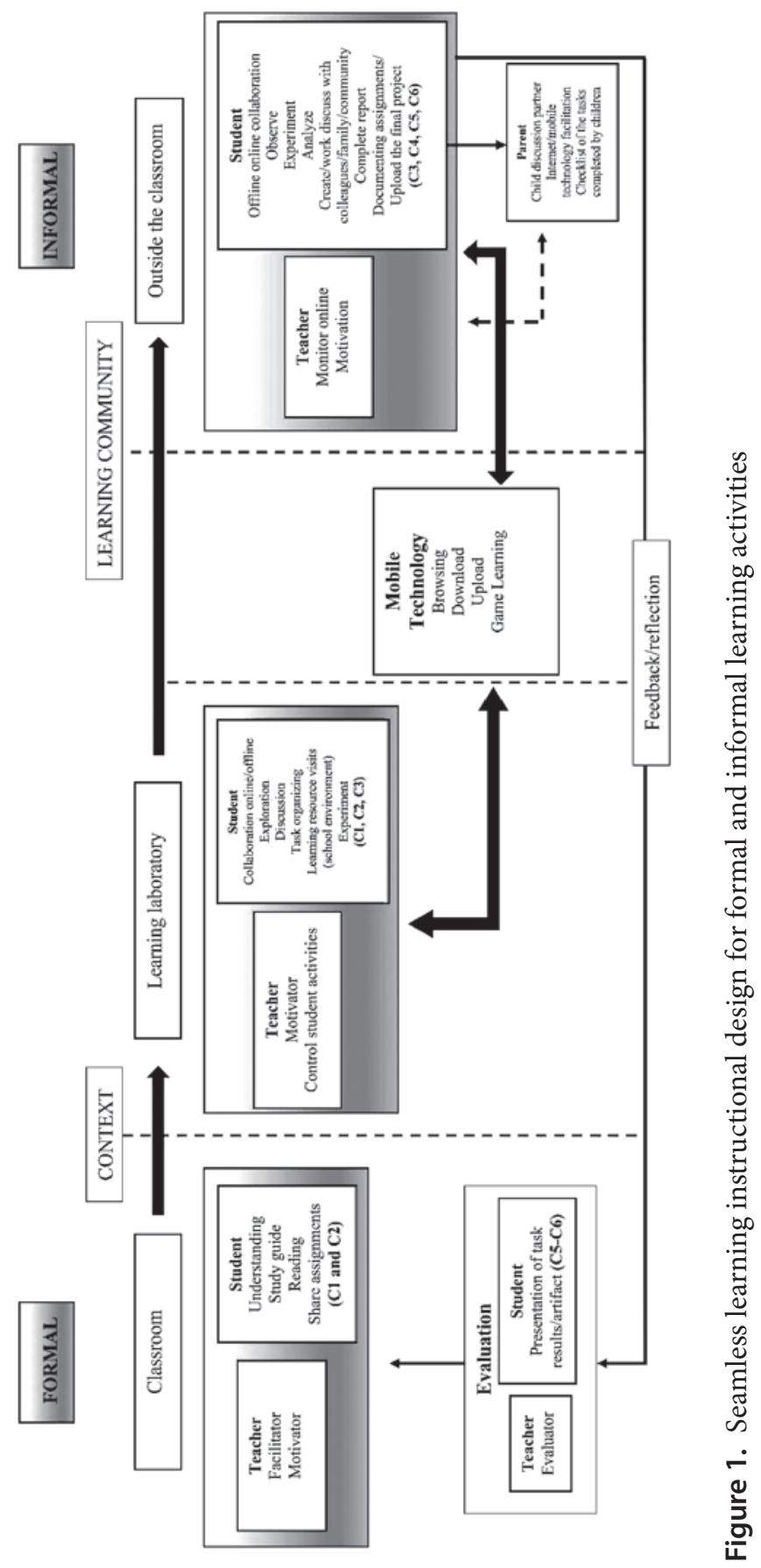


informal learning, students interact with family members and the community at large. Parents could facilitate student activities with mobile technology and provide learning environments capable of supporting the completion of given tasks. Parents are also required to have a checklist that shows all the tasks to be completed. Teachers' main tasks are only to monitor the students' activities online and they are not directly involved in activities outside the classroom. Additionally, parents act as learning information controller who are not allowed to be directly involved in completing the tasks. Hence, students' achievements could be different based on the child's ability.

\section{Evaluation Stage}

The teacher evaluates the completed tasks, thereby allowing the students to reflect and understand their strengths and weaknesses based on the assignments. Evaluation activities are the presentation of artifacts produced by students during building knowledge and experience. Evaluation is outside the classroom learning, and students submit the parents' checklists of all the tasks. This is the final activity in a series of previous ones, such as students' class activities, learning in the laboratory, out-of-class activity, as well as parents' guidance.

\section{Empirical Testing}

According to the validator, continuous learning has the capacity to provide students with high-quality learning experience. The students do not only depend on materials such as textbooks but most importantly learn to be able to manage themselves to complete the given tasks. In addition, tasks uncompleted in school were continued at home until school resumed. Based on the validator's suggestion, during implementation, there is need for the researchers to prepare a seamless learning activity guide for teachers and parents. Furthermore, its implementation should be able to guarantee a learning model which could be utilized by schools in facing the industrial revolution 4.0. The validation results for the instructional design of teachers' and students' activities based on seamless learning is shown in Table 3.

Table 3. Results of Validation by Design Experts

\begin{tabular}{llllllll}
\hline \multicolumn{1}{c}{ Component } & V1 & V2 & V3 & V4 & V5 & Average & Category \\
\hline Space & 4.7 & 4.3 & 4.7 & 4.3 & 4.3 & 4.5 & Very Good \\
\hline Time & 4.5 & 4.3 & 4.3 & 4.3 & 4.5 & 4.4 & Very Good \\
\hline Context & 4.3 & 4.5 & 4.5 & 4.5 & 4.3 & 4.4 & Very Good \\
\hline
\end{tabular}




\begin{tabular}{llllllll}
\hline \multicolumn{1}{c}{ Component } & V1 & V2 & V3 & V4 & V5 & Average & Category \\
\hline Community & 4.4 & 4.6 & 4.6 & 4.6 & 4.4 & 4.5 & Very Good \\
\hline Cognitive Tool & 4.7 & 4.7 & 4.3 & 4.7 & 4.3 & 4.5 & Very Good \\
\hline Artifact & 4.6 & 4.6 & 4.6 & 4.4 & 4.4 & 4.5 & Very Good \\
\hline
\end{tabular}

Table 3 shows that the components were given very good values. Based on the results the teachers' and students' activities in seamless formal and informal learning are valid and could be implemented as instructional designs according to the suggestions and criticisms of experts.

Table 4. Seamless learning matrix steps for formal and informal learning activities

\begin{tabular}{|c|c|c|c|}
\hline Classroom & $\begin{array}{l}\text { Laboratory learn- } \\
\text { ing }\end{array}$ & Outdoor learning & Evaluation \\
\hline \multicolumn{4}{|c|}{ Teachers } \\
\hline $\begin{array}{l}\text { - Prepare the learn- } \\
\text { ing facilities } \\
\text { - Preparing Learn- } \\
\text { ing Modules } \\
\text { - Prepare the } \\
\text { project }\end{array}$ & $\begin{array}{l}\text { Preparing } \\
\text { interactive } \\
\text { video, learning } \\
\text { video,education } \\
\text { game, Power- } \\
\text { Point slides, etc } \\
\text { - Motivator }\end{array}$ & Motivator & $\begin{array}{l}\text { - Prepare assess- } \\
\text { ments, both } \\
\text { verbal and non- } \\
\text { verbal tests } \\
\text { - Assess and pro- } \\
\text { vide feedback }\end{array}$ \\
\hline \multicolumn{4}{|c|}{ Students } \\
\hline $\mathrm{C} 1-\mathrm{C} 2$ & $\mathrm{C} 2-\mathrm{C} 4$ & C3-C6 & \\
\hline $\begin{array}{l}\text { - Understand study } \\
\text { guides } \\
\text { - Organize tasks that } \\
\text { are both offline } \\
\text { and online } \\
\text { - Discuss with } \\
\text { teachers and } \\
\text { friends }\end{array}$ & $\begin{array}{l}\text { - Read material } \\
\text { in e-books / } \\
\text { modules / online } \\
\text { teaching } \\
\text { - Complete indi- } \\
\text { vidual and group } \\
\text { tasks according } \\
\text { to ability and } \\
\text { understanding } \\
\text { - Look for } \\
\text { information in } \\
\text { learning resourc- } \\
\text { es with support } \\
\text { from parents }\end{array}$ & $\begin{array}{l}\text { - Access learning resources } \\
\text { (learning videos / games / } \\
\text { museums / community) } \\
\text { - Undergo the process of } \\
\text { exploration to experimen- } \\
\text { tation } \\
\text { - Complete tasks inde- } \\
\text { pendently with or without } \\
\text { mobile technology } \\
\text { - Build collaboration } \\
\text { - Report by uploading vide- } \\
\text { os, photos, works, etc. } \\
\text { - Discuss with parents / } \\
\text { friends / community }\end{array}$ & $\begin{array}{l}\text { - Presenting } \\
\text { works / results } \\
\text { - Completing } \\
\text { tasks, either on- } \\
\text { line or offline }\end{array}$ \\
\hline \multicolumn{4}{|c|}{ Parents } \\
\hline \multicolumn{3}{|c|}{$\begin{array}{l}\text { Being a good discussion partner } \\
\text { Providing smartphones / devices proportionally when needed } \\
\text { Giving support and motivation }\end{array}$} & $\begin{array}{l}\text { Making checklist } \\
\text { for task comple- } \\
\text { tion }\end{array}$ \\
\hline
\end{tabular}




\section{Documentation, analysis, and reflection on process and outcome}

Based on the results, the context reconstruction in a seamless learning design has the capacity to guide the activities of teachers and students. The limitations of mobile technology in schools could be solved through a learning laboratory and parents' support at home. The researchers continued with the development of the seamless learning matrix steps for formal and informal learning (Table 4). This matrix was key in the effectiveness of teacher and student learning activities.

\section{Discussion}

The use of instructional design and learning planning matrices is vital in elementary schools considering the fact that it accommodates the needs of teachers and students. According to Ersoy \& Sever (2019), it provides students with learning alternatives at the elementary level, thereby predicting the possible outcomes of their choices. The learning activities of teachers and students have clear cognitive outcomes ranging from $\mathrm{C} 1$ to $\mathrm{C} 5$ (see Table 4 above). One of the advantages of learning a planning matrix is the fact that it clearly shows teachers' and students' activities in formal-informal learning. This helps to sustain the learning and continues it at home. The limitations in the use of technology in schools could be replaced by maximizing the learning in laboratory and at home.

According to Mosvold \& Bjuland (2011), learning space is an environment where students are subjected to various experiences in relation to learning objects and the theories' core concepts. Also, the role of parents in the whole process is to support the students in developing their abilities. There is need for the learning environment to have a seamless relationship with the community and learning resources. Zhuang et al., (2017) reported that there is high correlation between the learning environment within the family at home and the school or workplace. The parents' support helps the students in completing their tasks using mobile phones, computers, internet, as well as interactions with the surrounding community. In addition, parents are not allowed to determine the outcomes based on their thoughts, but only act as companions and helping the children to complete the tasks based on the individual's abilities.

The parents are asked to provide a checklist on the completed tasks. The teachers evaluate the students' tasks at the end, giving feedback on the outcomes. The method used in this research, which involved activities between teachers and students in formal and informal learning, especially in schools with limited technology or computers, was not found in previous seamless designs. It is expected that 
this design will facilitate students' independence in learning, thereby improving their metacognitive abilities through various learning experiences.

\section{Conclusions}

The development of this seamless learning component seeks to facilitate formal and informal learning, especially in schools with limited use of mobile phones or technology. This research produced instructional design and learning planning matrices, which show the activities of teachers and students in both formal and informal contexts. Based on the recommendations of some experts, the continual implementation of this informal-formal seamless learning design has the capacity to build the independence and awareness of students in learning. The importance of guidebooks for teachers and parents when implementing this instructional design was also mentioned by the experts. Based on this, students are able to build learning experience and independence and achieve in accordance with their respective abilities.

\section{References}

Amhag, L. (2017). Mobile-Assisted Seamless Learning Activities in Higher Distance Education. International Journal of Higher Education, 6(3), 70. https://doi.org/10.5430/ ijhe.v6n3p70

Anderson, L. W., Krathwohl, D. R., Airasian, E. W., Cmikshank, K. A., Mayer, R. E., Pintrich, P. R., Raths, J., \& Wittrock, M. C. (2001). A taxonomy for learning, teaching, and assessing: A revision of Bloom's taxonomy of educational objectives. Longman.

Auguste, B., Kihn, P., \& Miller, M. (2010). Closing the talent gap: Attracting and retaining top-third graduates to careers in teaching. McKinsey \& Company, 46 p. https://doi.org/ http://mckinseyonsociety.com/closing-the-talent-gap/

Bian, H. (2004). Integrating environmental education into the elementary school curriculum. Chinese Education and Society, 37(4), 48-52. https://doi.org/10.1080/10611932. 2004.11031658

Dilger, B., Gommers, L., \& Rapp, C. (2019). The Learning Problems Behind the Seams in Seamless Learning. 9162. https://doi.org/10.1007/978-981-13-3071-1

Ersoy, A., \& Sever, I. (2019). Investigation of Decision-Making Skills of Fourth Grade Students According to Student and Teacher Opinions. Lnternational Electronic Journal of Elementary Education, 12(2), 167-182. https://doi.org/10.26822/iejee.2019257664

Mosvold, R., \& Bjuland, R. (2011). An Activity Theory View on Learning Studies. International Journal of Early Childhood, 43(3), 261-275. https://doi.org/10.1007/s13158-0110048-4 
Seow, P., Zhang, B., So, H., Looi, C., \& Chen, W. (2008). Towards a framework for seamless learning. May 2014.

Song, Y. (2018). Improving primary students' collaborative problem solving competency in project-based science learning with productive failure instructional design in a seamless learning environment. Educational Technology Research and Development, 66(4), 979-1008. https://doi.org/10.1007/s11423-018-9600-3

Song, Y., \& Kong, S. C. (2014). Going beyond textbooks: a study on seamless science inquiry in an upper primary class. Educational Media International, 51(3), 226-236. https://doi. org/10.1080/09523987.2014.968450

Sun, D., \& Looi, C. K. (2019). An Inspiration from Border Crossing: Principle of Boundary Activity for Integrating Learning in the Formal and Informal Spaces. Springer Singapore. https://doi.org/10.1007/978-981-13-3071-1

Sureda-Negre, J., Oliver-Trobat, M., Catalan-Fernändez, A., \& Comas-Forgas, R. (2014). Environmental education for sustainability in the curriculum of primary teacher training in Spain. International Research in Geographical and Environmental Education, 23(4), 281-293. https://doi.org/10.1080/10382046.2014.946322

van den Akker, J. (2013). Curricular Development Research as a Specimen of Educational Design Research. In T. Plomp \& N. Nieveen (Eds.), Educational Design Research: An Introduction (pp. 52-71). SLO, Enschede.

Wong, L.H. (2013). Analysis of Students' After-School Mobile-Assisted Artifact Creation Processes in a Seamless Language Learning Environment. Journal of Educational Technology \& Society, 16, 198-211. https://doi.org/10.2307/jeductechsoci.16.2.198

Wong, L.H., \& Looi, C.K. (2011). What seams do we remove in mobile-assisted seamless learning? A critical review of the literature. Computers and Education, 57(4), 2364-2381. https://doi.org/10.1016/j.compedu.2011.06.007

Zhang, B.H., \& Looi, C. (2011). Developing a sustainable education innovation for seamless learning. 15, 2148-2154. https://doi.org/10.1016/j.sbspro.2011.04.069

Zhuang, R., Fang, H., Zhang, Y., Lu, A., \& Huang, R. (2017). Smart learning environments for a smart city: from the perspective of lifelong and lifewide learning. Smart Learning Environments, 4(1), 6. https://doi.org/10.1186/s40561-017-0044-8 